\title{
Contents
}

\section{Data report: permeability and grain size of sediments, IODP Expeditions 372 and $375^{1}$}

Elizabeth J. Screaton, ${ }^{2}$ Cora Summerfield, ${ }^{2}$ John M. Jaeger, ${ }^{2}$ and Jonathan Whipple ${ }^{2}$

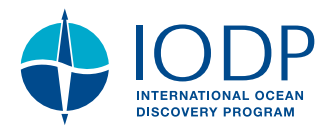

Keywords: International Ocean Discovery Program; IODP; JOIDES Resolution; Expedition 372; Expedition 375; Site U1517; Site U1518; Site U1519; Site U1520; Hikurangi Subduction Margin Coring, Logging, and Observatories; vertical permeability; grain size

\begin{abstract}
A total of 15 whole-round core samples from International Ocean Discovery Program Expeditions 372 and 375 were tested for vertical permeability. The samples were recovered from four sites. Sites U1517 and U1519 are located on the upper slope, Site U1518 is located near the trench, and Site U1520 is located seaward of the trench. Measured vertical permeability varied from $5.7 \times 10^{-19} \mathrm{~m}^{2}$ to $1.7 \times 10^{-16} \mathrm{~m}^{2}$. Unless cores were too consolidated to disaggregate, subsamples were taken and analyzed for grain size. The tested samples contained $35.4 \%-66.3 \%$ clay-sized $(<4 \mu \mathrm{m}), 32.7 \%-51.7 \%$ siltsized $(4-63 \mu \mathrm{m})$, and $0.5 \%-23.1 \%$ sand-sized $(>63 \mu \mathrm{m})$ fractions.
\end{abstract}

\section{Introduction}

International Ocean Discovery Program Expeditions 372 and 375 recovered cores from the Hikurangi Subduction Zone off the east coast of New Zealand (Barnes et al., 2019; Saffer et al., 2019) (Figure F1). In this study, we used flow-through permeability tests to measure the vertical permeability of 15 whole-round core samples. Subsamples from the core used for permeability testing were used for grain size analyses. Samples are from four sites. Site U1517 is located $\sim 35 \mathrm{~km}$ from shore on the upper slope of the Hikurangi margin at a water depth of $720 \mathrm{~m}$. Drilling at Site U1517 investi- gated the landslide mass and the gas hydrate stability zone of the Tuaheni Landslide Complex, and sediments consist primarily of clayey silt with sandy intervals (Barnes et al., 2019). Site U1518 is located $\sim 73 \mathrm{~km}$ from shore on the lower continental slope near the trench, and sediments are composed of silty clay or mud alternating with thin beds of silt to silty sand. Drilling at Site U1518 ( 2630 m water depth) investigated the Pāpaku thrust fault and the surrounding sediments (Saffer et al., 2019). Site U1519 is located on the upper continental slope $\sim 38 \mathrm{~km}$ from shore at a water depth of 1000 $\mathrm{m}$. This site was drilled to investigate the upper plate overlying a region that produces slow slip events; common lithologies include mud(stone), silt(stone), and sand(stone) (Saffer et al., 2019). Site $\mathrm{U} 1520$, at a water depth of $\sim 3520 \mathrm{~m}$, examined sediments on the incoming Pacific plate, $\sim 95 \mathrm{~km}$ from shore and $16 \mathrm{~km}$ east of the deformation front (Saffer et al., 2019). Site U1520 lithologies include mud with beds of silt and/or sand, pelagic carbonate, and volcaniclastic conglomerate (Saffer et al., 2019).

The objective of the testing was to help characterize the sediments that are part of the Hikurangi subduction zone. The permeability of sediments entering subduction zones can greatly affect fluid pressures during shallow subduction. Permeability testing allows development of permeability-porosity relationships that can be used for modeling pore pressure development and fluid flow.

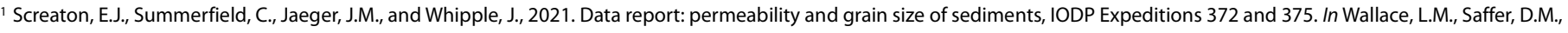
Barnes, P.M., Pecher, I.A., Petronotis, K.E., LeVay, L.J., and the Expedition 372/375 Scientists, Hikurangi Subduction Margin Coring and Observatories. Proceedings of the International Ocean Discovery Program, 372B/375: College Station, TX (International Ocean Discovery Program). https://doi.org/10.14379/iodp.proc.372B375.205.2021

2 Department of Geological Sciences, University of Florida, USA. Correspondence author: screaton@ufl.edu MS 372B375-205: Received 20 August 2020 . Accepted 18 November 2020 • Published 24 March 2021

This work is distributed under the Creative Commons Attribution 4.0 International (CC BY 4.0) license. (c) BY
} 
Figure F1. Locations of Expedition 372/375, Sites U1517-U1520. Figure was made using GeoMapApp and the default base map (Ryan et al., 2009). Inset shows location relative to Australia and New Zealand.

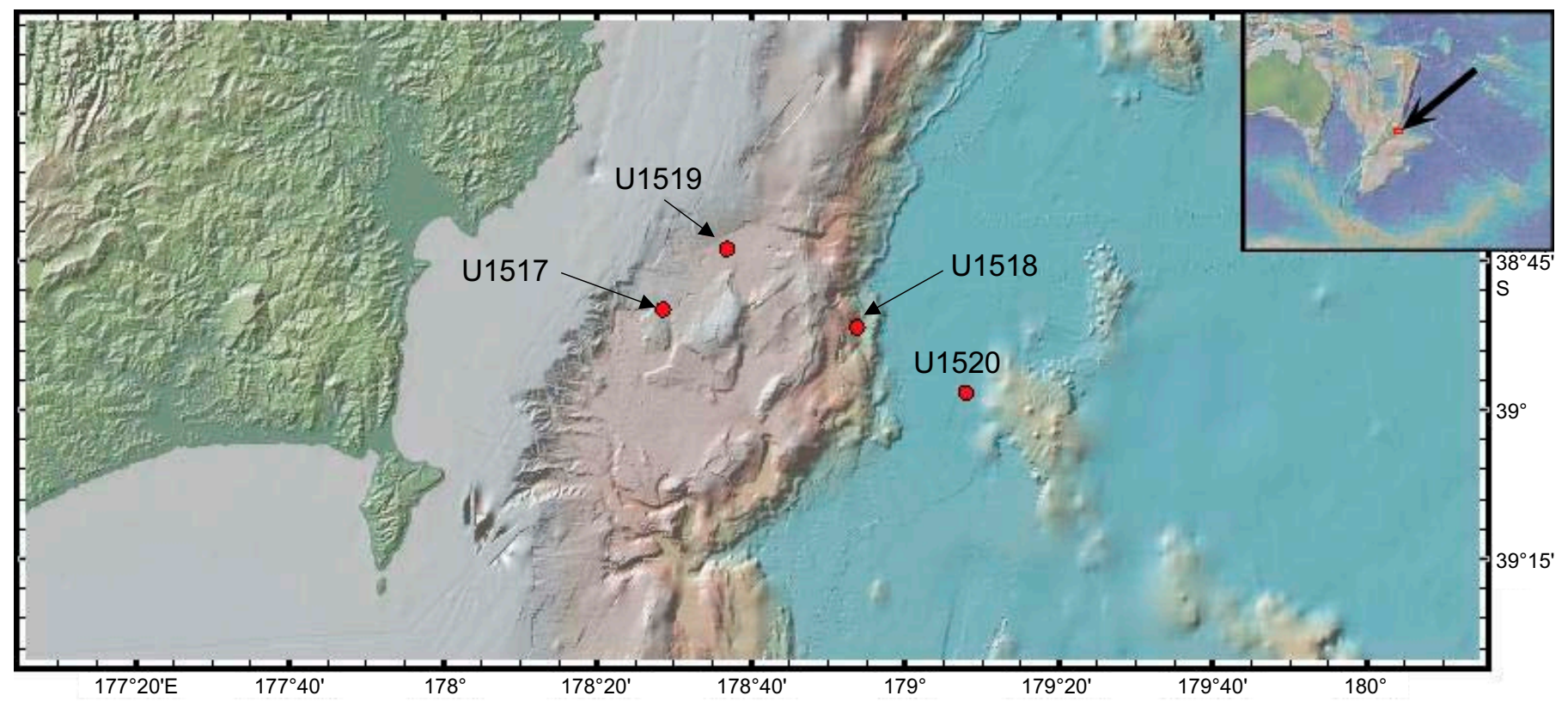

\section{Methods}

\section{Permeability tests}

The methods for permeability testing are similar to those of previous studies (e.g., James and Screaton, 2015) and were based on American Society for Testing and Materials (ASTM) designation D 5084-90 (ASTM International, 1990). Permeability tests used Trautwein Soil Testing Equipment Company's DigiFlow K. A cell is used to contain the sample, and a pump maintains isostatic effective stress on the sample (Figure F2). Two additional pumps are used to pump or remove water from the top and bottom of the sample. Deionized water was used as the fluid in the pumps, and a solution of $33 \mathrm{~g} \mathrm{NaCl}$ per liter of water permeated the sample. Pressure was transmitted from the deionized water to the permeant across a rubber membrane in an interface chamber (Figure F2).

The retrieved core samples from Expeditions 372 and 375 were stored in plastic core liners and sealed bags to prevent moisture loss. Samples were refrigerated at $4{ }^{\circ} \mathrm{C}$ until immediately before sample preparation. All tests were conducted with flow in the vertical direction (along the axis of the core) using the whole-round core. To provide freshly exposed surfaces, cores were trimmed on both ends using a cutting tool or wire saw, depending on core properties. Visual inspection was used to select portions of the core that were relatively uniform in composition and not disturbed or fractured. After the sample ends were trimmed, diameters of the trimmed whole-round cores ranged from 5.6 to $6.8 \mathrm{~cm}$ and sample heights ranged from 5.2 to $10.35 \mathrm{~cm}$. After trimming, the sample was placed in a rubber membrane and fitted with saturated porous disks and end caps. The membrane-encased sample was placed in the cell, which was then filled with deionized water. Fluid exchange occurs only through the flow lines connecting the end caps to the top and bottom pumps. A small confining pressure of $\sim 0.03 \mathrm{MPa}$ ( $5 \mathrm{psi}$ ) was applied to the water in the cell, and flow lines were flushed to remove any trapped air bubbles. After the flow lines were flushed, the sample was backpressured to either $\sim 0.28 \mathrm{MPa}$ (40 psi), $\sim 0.34 \mathrm{MPa}$
(50 psi), or $\sim 0.41 \mathrm{MPa}$ (60 psi) by concurrently ramping the cell pressure and the sample pressure to maintain a constant effective stress of $0.03 \mathrm{MPa}$ (5 psi). Because the whole-round samples were sealed immediately after the core liner was cut, the samples were expected to be near saturation prior to testing. Backpressuring at $0.28 \mathrm{MPa}$ (40 psi) for $\sim 24 \mathrm{~h}$ is sufficient to ensure full saturation under these conditions (ASTM International, 1990). A B test on each sample was used to check saturation. In a B test, the cell confining pressure was instantaneously increased by 10 psi and the sample response was measured. The ratio of sample pressure change to cell pressure change is the Skempton B coefficient, which is typically near 1 for soft to medium clays (Wang, 2000). A B test result of 0.95 is typically used to indicate saturation for soft to medium clays. This criterion is not applicable for more consolidated materials because compiled B coefficients for mudstone, sandstone, and limestone are $0.95,0.50-0.88$, and 0.25 , respectively (Wang, 2000). Samples with $\mathrm{B}$ coefficient less than 0.95 were given additional time for saturation or backpressure was increased. Saturation was assumed if the B value did not change with increased time and increased backpressure. Subsequently, the cell fluid pressure was increased while the sample backpressure was maintained, thus increasing the effective stress on the sample. This effective stress both consolidated the sample and pushed the flexible membrane against the sample to prevent flow from bypassing the sample. The expected in situ effective stress is generally much greater than what was reached in laboratory testing. As a result, the measured permeability values likely overestimate in situ conditions. On the other hand, they can be used to construct permeability-porosity relationships for use in fluidflow modeling (e.g., Daigle and Screaton, 2015).

For every sample, flow tests were performed at two or more different effective stress steps. Once the target effective stress was achieved for each step, cell pressure and backpressure were maintained. The sample was allowed to equilibrate for at least $12 \mathrm{~h}$ and generally for $24 \mathrm{~h}$. Throughout testing, inflows and outflows to the cell fluid were monitored to assess changes in sample volume, and 
Figure F2. Schematic of the permeability test system (top) and labeled photo of the permeability test system (bottom). The top, bottom, and cell pumps consist of $80 \mathrm{~mL}$ pistons that are moved up or down to infuse or extract water from the sample or cell. The interface chamber has a rubber diaphragm in the center to separate the seawater that is used as a permeant (bottom chamber) from the distilled water used in the pumps (top chamber). Deionized (DI) water is used in the cell pump and in the sample cell, which has a volume of $2300 \mathrm{~mL}$.
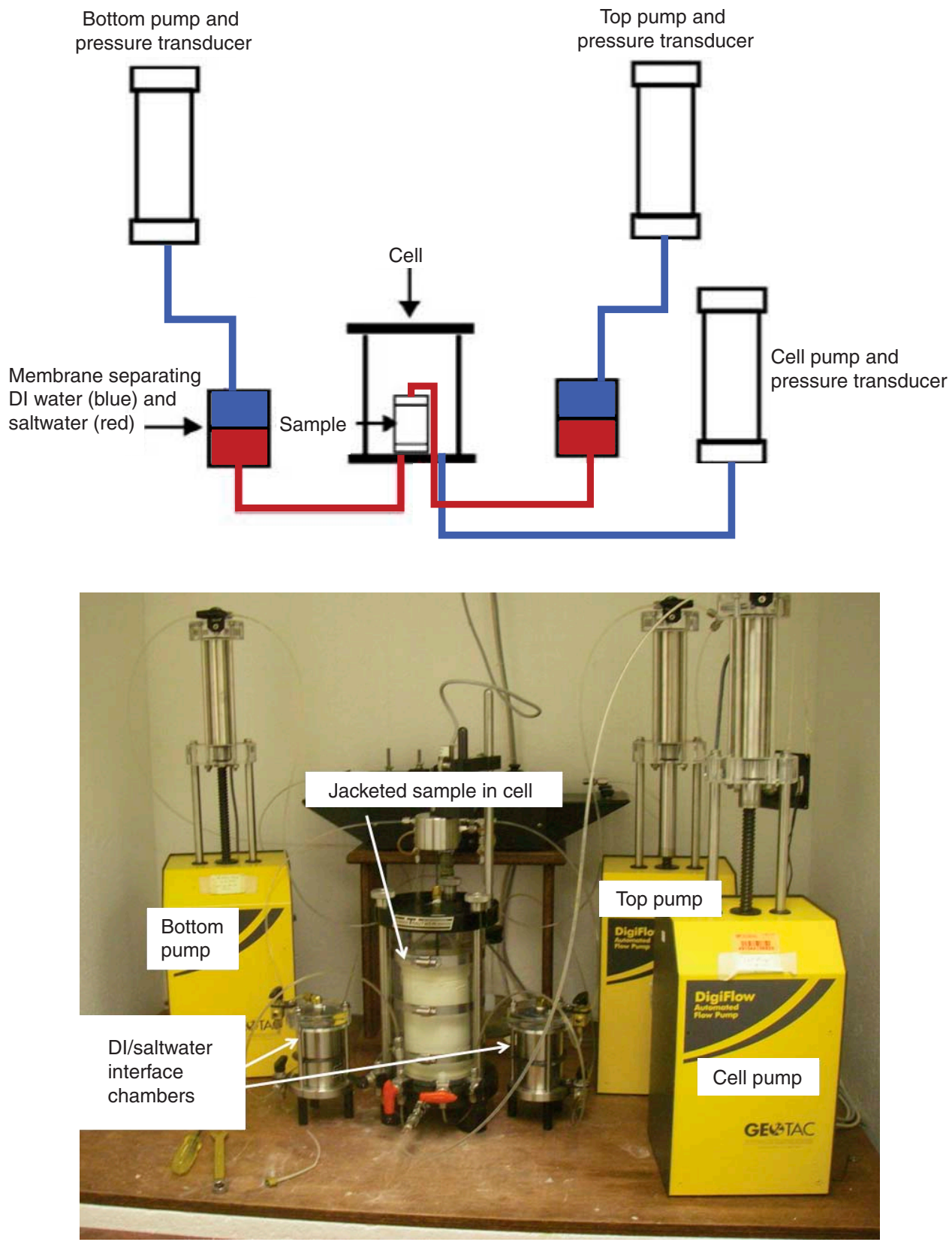

sample data were recorded every minute. Because fluid pressure in the closed hydraulic system was affected by temperature changes, testing was conducted within a closed cabinet to keep the internal temperature uniform. Testing temperatures were $26^{\circ} \pm 1^{\circ} \mathrm{C}$, unless otherwise noted in Table T1. At least three flow tests were performed at each effective stress level, and flow direction varied between tests. Flow tests were run by specifying pressures of the top and bottom pumps and recording flow rates into and out of the sample.

The pressure difference $(\Delta P)$ from the top and bottom pumps was converted to hydraulic head difference $(\Delta h)$ :

$$
\Delta h=\Delta P / \rho_{\mathrm{f}} \mathrm{g},
$$

where $\rho_{\mathrm{f}}=$ fluid density $\left(1021 \mathrm{~kg} / \mathrm{m}^{3}\right)$ and $\mathrm{g}=$ acceleration due to gravity $\left(9.81 \mathrm{~m} / \mathrm{s}^{2}\right)$.

Darcy's law was used to calculate the hydraulic conductivity:

$$
Q=-K A(\Delta h / \Delta l)
$$

where

$$
Q=\text { measured flow rate (in cubic meters per second), }
$$


Table T1. Results from laboratory permeability tests and grain size analyses, Sites U1517-U1520. Download in CSV format.

$K=$ hydraulic conductivity (in meters per second),

$A=$ the cross-sectional area of the sample (in square meters),

$\Delta h=$ the difference in head across the sample (in meters), and

$\Delta l=$ the length of the sample (in meters).

The hydraulic conductivity values were then converted to permeability (in square meters) using the following equation:

$$
k=(K \mu) /\left(\rho_{\mathrm{f}} \mathrm{g}\right),
$$

where

$$
\begin{aligned}
& \rho_{\mathrm{f}}=\text { fluid density }\left(1021 \mathrm{~kg} / \mathrm{m}^{3}\right), \\
& \mathrm{g}=\text { acceleration due to gravity }\left(9.81 \mathrm{~m} / \mathrm{s}^{2}\right) \text {, and } \\
& \mu=\operatorname{viscosity}(0.00093 \mathrm{~Pa} \cdot \mathrm{s}) .
\end{aligned}
$$

For the laboratory temperature (average $=26^{\circ} \mathrm{C}$ ) and fluid salinity $(33 \mathrm{~g} / \mathrm{L})$, a fluid density of $1021 \mathrm{~kg} / \mathrm{m}^{3}$ and viscosity of 0.00093 $\mathrm{Pa} \cdot \mathrm{s}$ were calculated based on relationships compiled by Sharqawy et al. (2010). Assuming reasonable water compressibility, density change due to the applied pressure was minor $(<0.1 \%)$. A $1 \mathrm{~h}$ interval of stable flow rates was averaged for the permeability calculations, and the standard deviation of the permeability during that interval was calculated to assess uncertainty. The fluctuations in the calculated permeability are likely caused by slight temperature variations. The resulting volume changes would cause temporary changes in measured flow rates. The time interval was selected based on where inflow best matched outflow, indicating steadystate conditions, and where the standard deviation was minimized.

The corresponding porosity for each effective stress level was calculated using the change in volume of fluid contained in the cell during each consolidation step. The volume change during consolidation was assumed to be solely a result of changes in sample porosity. Influences of material and apparatus stiffness were assumed to be negligible. Total sample volume $\left(V_{\mathrm{T}(0)}\right)$ was calculated using $\pi r^{2} h$, where $r$ is the radius of the core sample and $h$ is the height of the sample. Initial porosities $\left(n_{0}\right)$ for volume calculations were obtained from the shipboard moisture and density results; these shipboard data can be accessed at https://web.iodp.tamu.edu/OVERVIEW. We assumed that the porosity of the sample at the end of backpressure is similar to the initial porosity $\left(n_{0}\right)$ of the sample due to the small change in effective stress.

Using the initial porosity $\left(n_{0}\right)$, the volume of voids before the testing $\left(V_{\mathrm{v}(0)}\right)$ was calculated:

$$
V_{\mathrm{v}(0)}=n_{0} V_{\mathrm{T}(0)}
$$

Volume of solids $\left(V_{\mathrm{s}}\right)$ was calculated using:

$$
V_{\mathrm{s}}=V_{\mathrm{T}(0)}-V_{\mathrm{v}(0)}
$$

The change in volume of water in the cell $\left(\Delta V_{\mathrm{T}(1)}\right)$ was calculated using the difference of cell volumes between two consecutive steps (e.g., cell volume at backpressure and cell volume at first consolidation). The new total volume of the sample $\left(V_{\mathrm{T}(1)}\right)$ after pore spaces were reduced during the consolidation process was determined by subtracting the change in cell volume at the end of the consolidation step $\left(\Delta V_{\mathrm{T}(1)}\right)$ from the total sample volume $\left(V_{\mathrm{T}(0)}\right)$ :

$$
V_{\mathrm{T}(1)}=V_{\mathrm{T}(0)}-\Delta V_{\mathrm{T}(1)} \text {. }
$$

Using the calculated new total volume of the sample $\left(V_{\mathrm{T}(1)}\right)$, the new porosity at the end of the consolidation $\left(n_{1}\right)$ was calculated as

$$
n_{1}=\left(V_{\mathrm{T}(1)}-V_{\mathrm{s}}\right) / V_{\mathrm{T}(1)}
$$

\section{Grain size analyses}

Subsamples were extracted in $1.5 \mathrm{~cm}$ thick intervals from the permeability sample after completion of the permeability tests. Because the cores used for permeability testing were relatively consistent in composition, the subsamples were assumed to be representative. The subsamples were homogenized and then disaggregated in a solution of sodium hexametaphosphate (Calgon) to inhibit clay flocculation. Subsamples were also immersed in an ultrasonic bath for a minimum of $2 \mathrm{~h}$ to assist disaggregation. Two samples (375-U1520C-22R-4, 99-119 cm, and 29R-3, 64-84 cm) could not be tested for grain size because they were too consolidated to disaggregate using these methods.

A small aliquot of the homogenized sample was dried to determine water content, which was then used to establish the equivalent dry mass used in the particle size analysis. Once disaggregated, a subsample was wet sieved at $63 \mu \mathrm{m}$ to determine its sand-sized fraction. A separate subsample was wet sieved at $53 \mu \mathrm{m}$, and material smaller than $53 \mu \mathrm{m}$ was analyzed on a 5100 Micrometrics SediGraph (Coakley and Syvitski, 1991). The SediGraph emits X-rays that record the settling rates of particles suspended in a hexametaphosphate solution. The principle of Stokes' Law was used to calculate grain sizes. The SediGraph data were combined with the wetsieved results to normalize the mud and sand fraction to their relative masses to determine the proportion of sand-, silt-, and claysized particles. Clay-sized particles were defined as smaller than 4 $\mu \mathrm{m}$ based on the Wentworth grain size classification.

\section{Results}

Table $\mathbf{T} 1$ summarizes the effective stress and estimated porosity and permeability at each consolidation step as well as the grain size distribution for each sample.

Results are shown with plots of shipboard porosity in Figures F3, F4, F5, and F6 for Sites U1517, U1518, U1519, and U1520, respectively. Measured vertical permeability varied from $5.7 \times 10^{-19}$ $\mathrm{m}^{2}$ to $1.7 \times 10^{-16} \mathrm{~m}^{2}$. The tested samples contained $35.4 \%-66.3 \%$ clay-sized $(<4 \mu \mathrm{m}), 32.7 \%-51.7 \%$ silt-sized $(4-63 \mu \mathrm{m})$, and $0.5 \%-$ $23.1 \%$ sand-sized $(>63 \mu \mathrm{m})$ fractions. Permeability results are also plotted as a function of porosity (Figure F7). The results show a general trend of the logarithm of permeability varying with porosity. 
Figure F3. Shipboard porosity, permeability, and grain size analysis results, Site U1517.
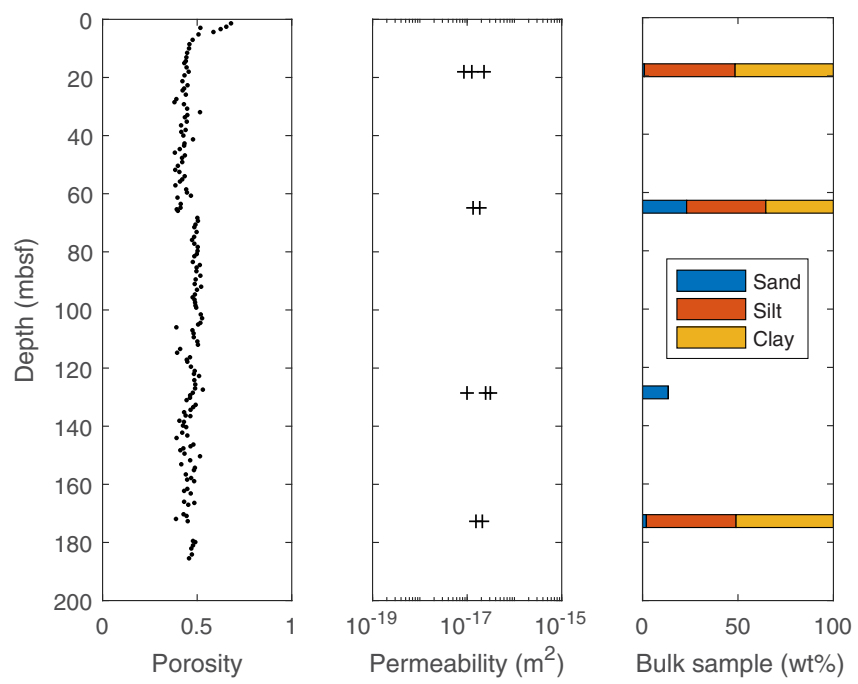

Figure F4. Shipboard porosity, permeability, and grain size analysis results, Site U1518.
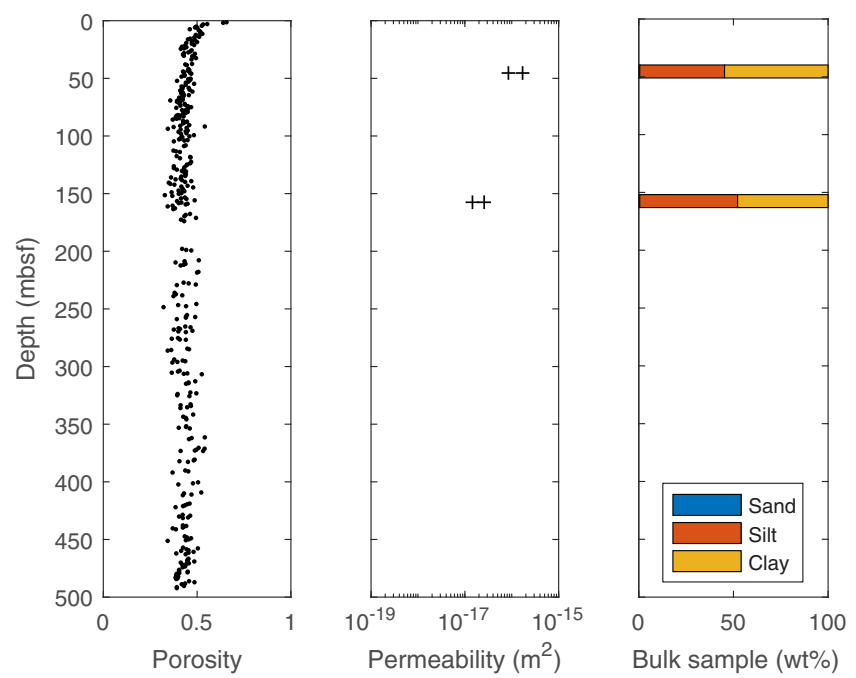

Figure F5. Shipboard porosity, permeability, and grain size analysis results, Site U1519.
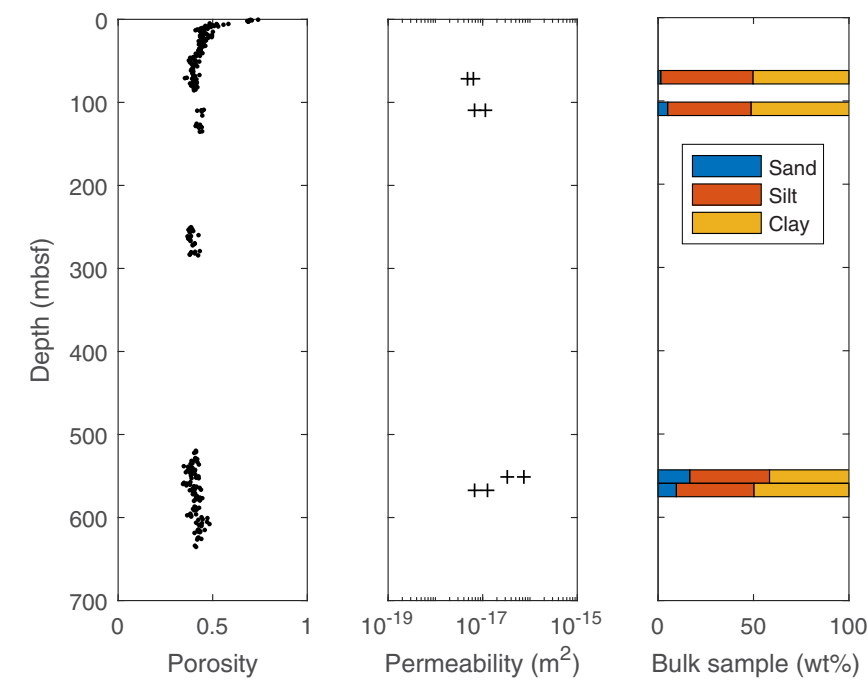

Figure F6. Shipboard porosity, permeability, and grain size analysis results, Site U1520.
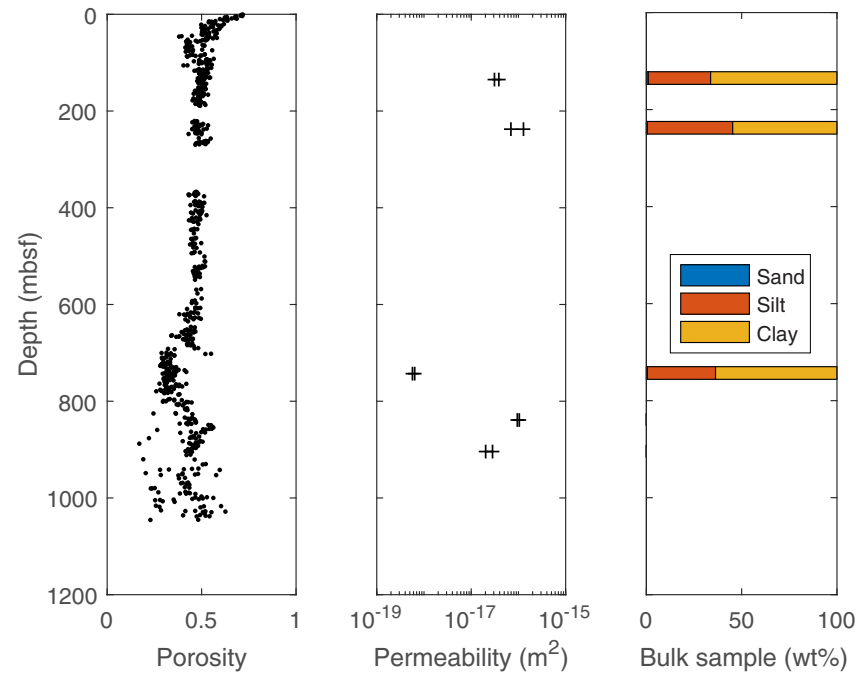
Figure F7. Permeability plotted as a function of porosity at the highest effective stress for all samples.

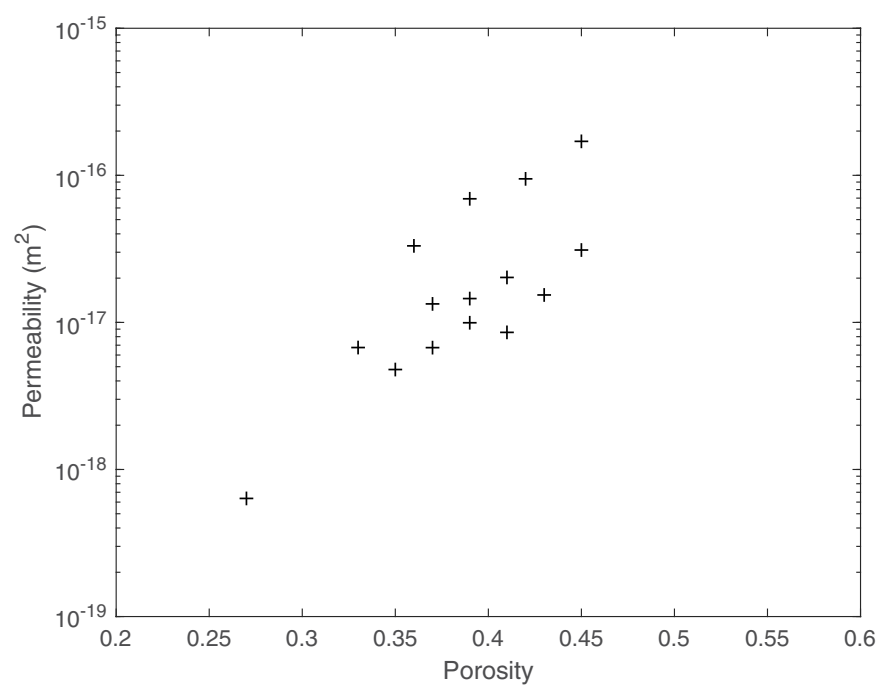

\section{Acknowledgments}

This research used samples and data provided by the International Ocean Discovery Program. Funding for this research was provided by a postcruise grant to E. Screaton from the U.S. Science Support Program. We thank the crew and technical staff of the JOIDES Resolution and the Expedition 372 and 375 scientific parties. Comments from an anonymous reviewer improved this manuscript.

\section{References}

ASTM International, 1990. Standard test methods for measurement of hydraulic conductivity of saturated porous materials using a flexible wall permeameter (Standard D5084). In Annual Book of ASTM Standards for Soil and Rock (Volume 04.08): Philadelphia (American Society for Testing Materials).

Barnes, P.M., Pecher, I.A., LeVay, L.J., Bourlange, S.M., Brunet, M.M.Y., Cardona, S., Clennell, M.B., Cook, A.E., Crundwell, M.P., Dugan, B., Elger, J., Gamboa, D., Georgiopoulou, A., Greve, A., Han, S., Heeschen, K.U., Hu, G., Kim, G.Y., Kitajima, H., Koge, H., Li, X., Machado, K.S., McNamara, D.D., Moore, G.F., Mountjoy, J.J., Nole, M.A., Owari, S., Paganoni, M., Petronotis, K.E., Rose, P.S., Screaton, E.J., Shankar, U., Shepherd, C.L., Torres, M.E., Underwood, M.B., Wang, X., Woodhouse, A.D., and Wu,
H.-Y., 2019. Expedition 372A summary. In Pecher, I.A., Barnes, P.M., LeVay, L.J., and the Expedition 372A Scientists, Creeping Gas Hydrate Slides. Proceedings of the International Ocean Discovery Program, 372A: College Station, TX (International Ocean Discovery Program). https://doi.org/10.14379/iodp.proc.372A.101.2019

Coakley, J.P., and Syvitski, J.P.M., 1991. SediGraph technique. In Syvitski, J.P.M. (Ed.), Principles, Methods, and Application of Particle Size Analysis: New York (Cambridge University Press), 129-142. https://doi.org/10.1017/CBO9780511626142.013

Daigle, H., and Screaton, E.J., 2015. Evolution of sediment permeability during burial and subduction. Geofluids, 15(1-2):85-105. https://doi.org/10.1111/gfl.12090

James, S.R., and Screaton, E.J., 2015. Data report: permeability of Expedition 344 sediments from the Costa Rica Seismogenesis Project. In Harris, R.N., Sakaguchi, A., Petronotis, K., and the Expedition 344 Scientists, Proceedings of the Integrated Ocean Drilling Program, 344: College Station, TX (Integrated Ocean Drilling Program). https://doi.org/10.2204/iodp.proc.344.202.2015

Ryan, W.B.F., Carbotte, S.M., Coplan, J.O., O'Hara, S., Melkonian, A., Arko, R., Weissel, R.A., Ferrini, V., Goodwillie, A., Nitsche, F., Bonczkowski, J., and Zemsky, R., 2009. Global multi-resolution topography synthesis. Geochemistry, Geophysics, Geosystems, 10:Q03014. https://doi.org/10.1029/2008GC002332

Saffer, D.M., Wallace, L.M., Barnes, P.M., Pecher, I.A., Petronotis, K.E., LeVay, L.J., Bell, R.E., Crundwell, M.P., Engelmann de Oliveira, C.H., Fagereng, A., Fulton, P.M., Greve, A., Harris, R.N., Hashimoto, Y., Hüpers, A., Ikari, M.J., Ito, Y., Kitajima, H., Kutterolf, S., Lee, H., Li, X., Luo, M., Malie, P.R., Meneghini, F., Morgan, J.K., Noda, A., Rabinowitz, H.S., Savage, H.M., Shepherd, C.L., Shreedharan, S., Solomon, E.A., Underwood, M.B., Wang, M., Woodhouse, A.D., Bourlange, S.M., Brunet, M.M.Y., Cardona, S., Clennell, M.B., Cook, A.E., Dugan, B., Elger, J., Gamboa, D., Georgiopoulou, A., Han, S., Heeschen, K.U., Hu, G., Kim, G.Y., Koge, H., Machado, K.S., McNamara, D.D., Moore, G.F., Mountjoy, J.J., Nole, M.A., Owari, S., Paganoni, M., Rose, P.S., Screaton, E.J., Shankar, U., Torres, M.E., Wang, X., and Wu, H.-Y., 2019. Expedition 372B/375 summary. In Wallace, L.M., Saffer, D.M., Barnes, P.M., Pecher, I.A., Petronotis, K.E., LeVay, L.J., and the Expedition 372/375 Scientists, Hikurangi Subduction Margin Coring and Observatories. Proceedings of the International Ocean Discovery Program, 372B/375: College Station, TX (International Ocean Discovery Program). https://doi.org/10.14379/iodp.proc.372B375.101.2019

Sharqawy, M.H., Lienhard, J.H., and Zubair, S.M., 2010. The thermophysical properties of seawater: a review of existing correlations and data. Desalination and Water Treatment, 16:354-380. http://hdl.handle.net/1721.1/69157

Wang, H.F., 2000. Theory of Linear Poroelasticity with Applications to Geomechanics and Hydrogeology: Princeton, New Jersey (Princeton University Press). https://www.jstor.org/stable/j.ctt1jktrr4 